\title{
Urbanismo, ideologia e o comum: notas sobre a sociedade urbana pós-capitalista
}

\author{
Urbanism, ideology and the common: \\ notes on the post-capitalist urban society
}

Victor Augusto Campos Alves [l]

\section{Resumo}

Este artigo tem por objetivo discutir as relações entre algumas contribuições consagradas dentro da teoria urbana, fazendo um contraponto lefebvriano ao problema da cidade e da transformação radical da sociedade. Ao tratar do tema do urbanismo, do papel das ideologias e dos novos movimentos sociais, foi empreendido um esforço de postular a validade da problemática de Marx para os dias atuais e de discutir a programática da transição para o comunismo tendo como horizonte uma nova "sociedade urbana" e tendo em conta também o problema do direito. Sob a rubrica do comum, o texto busca trazer alguns autores (neo) marxistas que retomam esste conceito e indicar de que modo uma interpretação não economicista da obra marxiana permite vislumbrar novos caminhos revolucionários. Palavras-chave: comum; ideologia urbana; sociedade urbana; revolução urbana; direito à cidade

\begin{abstract}
This article aims to discuss the relations among some established contributions within urban theory, making a Lefebvrian counterpoint to the problem of the contemporary city and of the radical transformation of society. In addressing the theme of urbanism, the role of ideologies and the new social movements, we postulate the validity of Marx's ideas for the current times and discuss the program of transition to communism, in light of a new "urban society" and taking into account the problem of law. Under the heading of common, the text discusses the thought of some (neo) Marxist authors who revisit this concept and indicates how a heterodox interpretation of Marx's work allows us to envision new revolutionary paths.
\end{abstract}

Keywords: common; urban ideology; urban society; urban revolution; right to the city. 


\section{Introdução}

Uma série de movimentos urbanos emergiu no cenário mundial nas últimas décadas e fez reaquecer o debate acerca do urbanismo, do planejamento e da revolução no seio das vertentes teóricas críticas. Na verdade, as lutas atuais observadas na tomada das praças e de outros locais públicos em cidades como Cairo, Istambul, Nova York, Barcelona e nas capitais brasileiras se inserem em um contexto histórico mais amplo de reivindicações de trabaIhadores desde o século XVIII. Como mostra David Harvey, a base urbana de diversos movimentos sociais oriundos da luta de classe é expressiva e remonta à Paris da Revolução Francesa de 1789, passando pelos acontecimentos de 1830, 1848, até a Comuna de 1871. Além disso, o importante papel das cidades em greves, comunas, sovietes, levantes, insurreições, nos movimentos de 1968, nas lutas antiglobalização e nos movimentos revolucionários no México (em 2000 e 2007) e na Bolívia (2003 e 2005) vem somar-se às experiências recentes de insatisfação popular, em especial, contra a neoliberalização (Harvey, 2014, pp. 209-210). Ainda assim, há, nessas modalidades de luta contemporâneas, um caráter ao mesmo tempo espontâneo e fugaz que merece atenção e uma pesquisa mais aprofundada. Mesmo que continuem existindo sindicatos e partidos, veIhos instrumentos da política, a nova luta tem se pautado pela existência das redes e pela ausência tanto de lideranças como de uma programática clara e consciente, fatos que podem estar na raiz da "trajetória errática" da maioria dos movimentos atuais (ibid., p. 215). É, nesse sentido, que Harvey se pergunta se à cidade (e às lutas que a têm como palco) pode ser atribuído um fundamento novo e diverso para as transformações efetivas no capitalismo, ou se se trata apenas de um fator secundário, ou de um desdobramento daquilo que seria o essencial: a luta operária fabril. Em suma, dentro do marxismo ortodoxo, "essas lutas são interpretadas como algo mais voltado para questões de reprodução do que de produção ou sobre direitos, soberania e cidadania e, portanto, não sobre classe" (ibid., p. 217).

No bojo dos fracassos do socialismo real e das suas inclinações totalitárias, as esquerdas têm concluído seja pela necessidade de perecimento imediato do Estado, seja pela organização autônoma coletiva de forma paralela ao Estado. Esse último caso pressupõe que o poder central pode ir diminuindo à medida que movimentos organizados da sociedade civil vão tomando a frente na importância e no governo das questões sociais. A defesa da "horizontalidade" e da "não hierarquia" parece ser questão de ordem no debate de esquerda, o qual, por vezes, não tem levado em conta o problema de escala das questões mundiais, como, por exemplo, a destruição dos recursos naturais do planeta (ibid., pp. 224-225). Assim é que o próprio Harvey, e boa parte da literatura, identifica na figura de Henri Lefebvre o ponto de partida para a tomada de consciência do papel do urbano na luta anticapitalista, tendo em vista as suas proposições e a sua utopia (o vir a ser possível e tendencial) acerca da cidade comunista.

É nesse sentido que este artigo procura resgatar algumas das contribuições ao debate 
sobre a cidade, a sua conceituação e o seu papel na superação da sociedade capitalista. Neste artigo, foi empreendido um breve reexame da literatura relevante no tema da sociologia urbana de um ponto de vista marxista, bem como uma interface entre os autores mais importantes nesse tema e os problemas atuais do urbanismo. Foram apontados os desafios para uma saída teórica e política à esquerda que tenha como inspiração a tese comunista do urbano lefebvriano.

A primeira parte do texto (segundo item) dedica-se a analisar os méritos e problemas atinentes às formulações sobre o tema das cidades em teóricos como Georg Simmel, Louis Wirth e Robert Park, relacionando-os e contrapondo-os ao arcabouço marxiano. Em sequência, na terceira seção, é apresentada uma das visões correntes sobre a ideologia no meio marxista para que seja explorada a relação das ideologias e o urbanismo, enfrentando os argumentos de Manuel Castells e Lefebvre, principalmente, sobre o tema. A seção quarta debruça-se sobre o tema dos movimentos contemporâneos identificados pela literatura sob o âmbito da construção do comum, bem como avança no desenvolvimento da noção lukácsiana de ideologia e nas possibilidades que abre. Nesse ponto do texto, explora-se também como o problema do direito, enquanto forma capitalista por excelência, pode ser tratado, tanto nas saídas propostas por alguns movimentos sociais, como na expressão lefebvriana do "direito à cidade". A seção quinta traz as considerações finais, relações e conclusões que podem ser exploradas para uma agenda de pesquisa e militância possível.

\section{Simmel, Escola de Chicago e marxismo}

A cidade transformou a luta com a natureza pela vida em uma luta entre os homens pelo lucro. (Simmel, 1967, p. 21)

Embora aponte para a inexorabilidade (ou naturalidade) da formação urbana capitalista, é possível dizer que o filósofo Georg Simmel conhece a natureza do problema da modernidade capitalista. Para ele, a economia do dinheiro e a racionalidade instrumental são duas faces da mesma moeda, bem como reconhece que a fonte das contradições e da especificidade da cidade é a divisão do trabalho. Assim, esse autor posiciona corretamente o avanço da economia monetária e das trocas impessoais como algo que distingue esse espaço do espaço rural (ibid., pp. 10-11). Pode-se dizer, reformulando o argumento de Simmel em termos marxianos, que é com o surgimento histórico da medida do homem pelo valor (valor de troca) que surgem as noções de tempo e de trabalho abstrato e, com isso, criam-se as condições de possibilidade dessa nova vida mental.

Löwy (2014), tratando das semelhanças entre Marx e Weber, pontua que ambos "compartilham uma visão do capitalismo moderno como o universo em que 'os indivíduos são dirigidos por abstrações' (Marx), em que relações impessoais e 'coisificadas' [Versachlicht] substituem as relações pessoais de dependência [...]" (p. 18), ideia que poderia, a meu ver, servir também à relação entre Marx e Simmel. Noutro trecho, agora dos manuscritos de Marx, explicita-se também a posição de Marx quanto ao dinheiro no sistema capitalista, reforçando o 
ponto que há entre ambos os autores: "A quantidade de dinheiro se torna cada vez mais seu único atributo poderoso [do homem]; assim como ele reduz todo o ser a sua abstração, reduz-se ele em seu próprio movimento a ser quantitativo" (Marx apud Lowy, 2014, p. 32). É possível acrescentar ainda, a partir da análise de Simmel sobre a atitude blasé ou de "antipatia latente" dos citadinos modernos, que não só essa atitude efetua "as distâncias e aversões sem as quais esse modo de vida não poderia absolutamente ser mantido" (1967, p. 17), como demonstram que, para a superação do capitalismo num viés marxista, seria necessária a superação das condições também culturais (superestruturais, em certo sentido) que habitam 0 universo da cidade capitalista, e não só a superação da economia monetária pela planificação e pela economia política crítica. ${ }^{1}$

No entanto, parece claro que, ao fazer menção a alguns conceitos como cidade, trabaIho e dinheiro como instâncias trans-históricas, Simmel perde em poder analítico e naturaliza relações sociais que estão historicamente posicionadas. Ainda assim, esse autor dá atenção a aspectos importantes do capitalismo enquanto forma de vida, ou seja, como sistema que contém mecanismos de dominação social para além da esfera produtiva (econômica), algo que será retomado pelos frankfurtianos e pelo marxismo weberiano, sob o nome de crise da modernidade ou crise da racionalidade. Mais uma vez deve ser pontuado que o tema está presente na literatura marxista, na weberiana e também em Simmel, que influenciou ambas as escolas. Vale ressaltar, nesse diapasão, que a primeira geração da Escola de Frankfurt percebe o processo civilizatório como de "desencantamento do mundo" e de "racionalização" crescente, culminando na sociedade industrial e burocrática (Lowy, 2014, p. 118). Não se trata, porém, de qualquer tipo de racionalização, mas de uma razão "eclipsada", instrumental ou subjetiva, como analisa Horkheimer (2015) ao longo do seu Eclipse da razão. Assim, é possível perceber a afinidade entre esse autor e as análises de Simmel, o qual destaca que "o desenvolvimento da cultura moderna é caracterizado pela preponderância do que se poderia chamar de o 'espírito objetivo' sobre o 'espírito subjetivo'" (Simmel, 1967, p. 22).

A análise de Simmel nos conduz a conclusões ambíguas acerca da modernidade capitalista, assim como a de Marx. Simmel se aproxima da admiração de Marx e Engels, no Manifesto comunista, pela revolução burguesa e por aquilo com que ela rompeu em relação à Antiguidade: "vínculos opressivos que se haviam tornado destituídos de significação" (ibid., p. 23). A burguesia "submeteu o campo à cidade. Criou grandes centros urbanos; aumentou prodigiosamente a população das cidades em relação à dos campos e, com isso, arrancou uma grande parte da população do embrutecimento da vida rural" (Marx e Engels, 2010, p. 44; grifos meus). Por outro lado, Simmel chega a dizer, com incrível semelhança à análise de Marx, que se nota, em alguns pontos, "um retrocesso na cultura do indivíduo com relação à espiritualidade, delicadeza e idealismo" (Simmel, 1967, p. 22). Essa discrepância, como se sabe, resulta da crescente divisão do trabalho, expondo o crescente abismo entre os avanços culturais e tecnológicos do gênero humano e aquilo que é efetivamente apreendido pelo indivíduo isolado, cada vez mais alienado. Não é necessário dizer que o tema da alienação é caro a Marx, e que um dos 
pontos centrais de crítica de Marx é, justamente, que o capitalismo desenvolve suas forças produtivas e o conhecimento geral da humanidade por meio da "fragmentação do trabalho social - ou seja, à custa do estreitamento e esvaziamento do indivíduo particular" (Postone, 2014, p. 46).

Apesar desses desenvolvimentos, se a proposição de Simmel é refinada e se afasta de alguns pressupostos que esvaziam o conteúdo propriamente social do espaço, ${ }^{2}$ outros teóricos influenciados por ele tomaram outros caminhos. 0 texto de Robert Park (1967) presente na mesma coletânea organizada por Gilberto Velho, $A$ cidade: sugestões para a investigação do comportamento humano no meio urbano, adere a uma visão tradicional acerca do que é a modernidade e se filia à tradição liberal de pensamento político e social. Contrariamente, as noções marxistas trabalham com as contradições e a crítica dos modernismos entendendo as determinações e legalidades que agem tendencialmente sobre os indivíduos no capitalismo e especificamente no urbano. Assim, a linha de investigação, dita marxista, não parte das premissas adotadas por Park e, em certo sentido, funda sua razão de ser no ataque a noções como a de homo economicus, à ideia de natureza humana enquanto tal $^{3}$ ou do espaço como expressão ou reflexo da alma do homem. Mesmo tomando por base um ponto de vista externo à tradição marxista, algumas análises presentes no texto de Park podem ser problematizadas, no que diz respeito à crítica ao liberalismo econômico e à predisposição natural do homem às trocas (Polanyi, 2012); os problemas de se entender as discriminações e segregações como meras conveniências e gostos pessoais, colocando em pauta a existência de um ordenamento dos discursos na modernidade e 0 atravessamento dos sujeitos por esses mesmos discursos (Foucault, 1999); e no seu entendimento de que há uma cisão clara entre interesses e sentimentos; racionalidade e irracionalidade. A crença presente no texto parkiano acerca do isolamento e do alcance da racionalidade é bastante discutível. Além disso, há quem enxergue o próprio racismo e a segregação descritos nos textos da sociologia urbana produzida em Chicago como partes integrantes da modernidade (constituintes de uma racionalidade) e não como um distúrbio desta (ver Hardt e Negri, 2016).

Ainda que seja possível fazer essa dura crítica, deve-se ressaltar que a sociologia urbana trouxe consigo uma inovação metodológica importante, que visou dar relevância ao contato direto e à descrição acurada da situação concreta vivida por grupos sociais excluídos. Esse fato precisa ser articulado teoricamente com as formulações marxianas para o aproveitamento do seu alcance político radical. Como veremos, importantes lições vêm sendo tiradas dos trabalhos de cunho antropológico, os quais pagam tributo à tradição inaugurada em Chicago.

A discussão e a crítica que se seguiu nos autores de corte marxista a respeito das formulações feitas em Chicago (e mesmo entre eles) se dão em torno da noção de ideologia. As acusações, de um lado a outro, foram eminentemente pautadas pela ideia de que cabe àqueles que desconhecem o fundamento das relações sociais a pecha de ideólogos. Nesse sentido, cabe fazer um pequeno parêntese para tratar das diferentes formas que esse conceito fora recebido pela tradição; vejamos do que se trata. 


\section{A ideologia urbana: conceito e crítica}

A ideologia é um conjunto lógico, sistemático e coerente de representações (ideias e valores) e de normas ou regras (de conduta) que indicam e prescrevem aos membros de uma sociedade o que devem pensar e como devem pensar, [...] o que devem fazer e como devem fazer. (Chauí, 2013, p. 117)

Para completar a posição de Marx e Engels, de $A$ ideologia alemã, falta acrescentar ainda mais um termo da exposição de Chaui:

Ela [a ideologia] é, portanto, um conjunto de ideias ou representações [...] cuja função é dar aos membros de uma sociedade dividida em classes uma explicação racional para as diferenças sociais, políticas e culturais, sem jamais atribuí-las à divisão da sociedade em classes. [...] a função da ideologia é ocultar a divisão social das classes. (Ibid., p. 117)

Assim, completa-se o construto inicial que pretendem dar Marx e Engels ao conceito. Para eles, a referência aos liberais como ideólogos, por exemplo, prescinde de uma noção acerca da mentira intencional (ou da má-fé) acerca de uma formulação. 0 que dá a um arcabouço teórico o seu caráter ideológico é a não observância da história e da divisão social da sociedade em classes como aquilo que determina, em última instância, a verdade das relações sociais modernas. 0 registro liberal, para seguirmos nesse exemplo, não é deliberadamente mentiroso, porém é falso. Acredita-se estar transmitindo a verdade das coisas quando se diz, com Adam Smith, por exemplo, que o homem possui naturalmente a propensão a trocar e barganhar. Trata-se de um registro cientificamente falso e que cumpre a função de obliterar a cisão profunda entre aqueles que trabalham e aqueles que exploram; entre homens e mulheres, brancos e negros.

Sob esse ponto de vista, as ideias dominantes de uma época são as da classe dominante e expressam a consciência de um ser humano que se alienou de si. Depreendem-se da realidade concreta os fatos da aparência, da superfície da sociedade; expressão inversa do mundo. Assim, os processos históricos são naturalizados e o que se apresenta idealmente nada mais é do que metonímia do real (lasi, 2018).

No entanto, após essa primeira formulação, Marx põe à frente outra maneira de conceituar o problema da ideologia, forma esta que servirá de base aos estudos marxistas até o primeiro quartel do século XX. Isso se deu porque o teor de $A$ ideologia alemã só será tornado público bem depois da morte de Marx e quase cem anos após a sua feitura em 19321933). ${ }^{4}$ (Assim, é na Contribuição à crítica da economia política que Marx afirma que as relações de produção configuram, em sua totalidade, "a estrutura econômica da sociedade, a base real sobre a qual se eleva uma superestrutura jurídica e política e à qual correspondem formas sociais determinadas de consciência" (Marx, 2008, p. 47). Dirá Marx que a consciência é determinada pelas condições reais concretas da sociedade e não o contrário. Desse modo, "convém distinguir sempre a transformação material das condições econômicas de produção [...] e as formas jurídicas, políticas, religiosas, artísticas ou filosóficas, em resumo, as formas ideológicas sob as quais os homens adquirem consciência desse conflito e o levam até o fim" (ibid., p. 48). Essa maneira de 
conceituar a ideologia foi que deu as bases das teorias marxistas anteriores à publicação de $A$ ideologia alemã e forneceu os elementos para a modificação do conceito ao longo do século XX. Assim, cabe defini-la como um conjunto de ideias, consciência adquirida pelos homens por meio da qual eles norteiam as suas ações. 0 pressuposto para essa aquisição é a sua contraparte no real, a sua origem nas relações sociais concretas.

Observaremos, ao longo deste artigo, de que modo esses conceitos sobre a ideologia foram apropriados na discussão do urbanismo como ideologia. Feito esse preâmbulo sobre algumas formulações acerca da ideologia na linha de pensamento marxista, pode-se avançar para o problema da ideologia e o urbanismo. Tendo-se em vista que o termo é caro à tradição marxista, ele aparece, no tratamento da questão urbana, no texto de marxistas como Henri Lefebvre e Manuel Castells, já com a conotação de $A$ ideologia alemã.

\section{Marxismo(s) e a ideologia urbana}

Assim, Castells faz importante crítica ao problema da ideologia urbana em seu The urban question, chamando a atenção para os problemas de interpretação científica acerca do urbano nas teorias, sejam elas liberais ou críticas. A interpretação marxista tradicional, empreendida por Castells, acerca das formulações clássicas oriundas de Chicago, nos esclarece a incorreção, por exemplo, em dizer que a fragmentação das atividades e a especialização produtiva teriam advindo das cidades modernas; a forma citadina causando o fenômeno da diversificação produtiva e da divisão técnica do trabalho. Esses fatos fundam a complexidade urbana celebrada por Simmel, Park e Wirth, mas têm sua origem na invenção do trabalho livre e da necessidade de ganhos de produtividade (Castells, 1977, p. 81).

A predominância de "relações secundárias" sobre as "primárias" e a individualização acelerada das relações também expressam essa necessidade política e econômica do novo modo de produção de constituir como "cidadãos livre e iguais" os respectivos suportes dos meios de produção e da força de trabaIho. ${ }^{5}$ (Ibid., p. 81)

Com isso, Castells busca rejeitar a existência de uma "cultura urbana". Essa crítica advém do fato de que não é possível atribuir ao elemento ecológico-formal da cidade o caráter de produtor (isolado) das características urbanas modernas. ${ }^{6}$ Ele também nos informa que não há como dizer, por exemplo, que a cidade se define apenas por um tamanho, pela quantidade de pessoas ou densidade específicas do local como quer Wirth (1967). Assim, as alterações nas dimensões e diferenciações urbanas são consideradas elas mesmas "produto e expressão de uma estrutura social e das suas leis de transformação" (Castells, p. 83). É, nesse sentido, que os escritos sobre "cultura urbana" são considerados mitos, ou ideologias, para Castells. Para esse autor, eles fornecem atalhos e ocultam a base de contradições sociais e a divisão de classe que facilita a sua emergência enquanto ideologia.

No entanto, se a crítica foi dirigida aos teóricos liberais de Chicago, ela também foi feita à esquerda; aos escritos de Henri Lefebvre. Na visão de Castells, além de apontar para uma utopia e não conferir a primazia da mudança 
social para uma luta de classes que tenha como alvo a ditadura do proletariado, ${ }^{7}$ Lefebvre incorre em erro mais grave. Segundo o autor espanhol, o termo "urbano" não pode ser usado inocentemente:

ele sugere a hipótese de uma produção de conteúdo social (o urbano) por uma forma trans-histórica (a cidade), e, além disso, ele expressa toda uma concepção geral da produção de relações sociais, isto é, de fato, uma teoria de mudança social, uma teoria da revolução. (Castells, 1977, p. 89)

Em suma, Castells não parece acreditar na possibilidade de um processo revolucionário que seja pautado no tema do urbano e que não esteja necessariamente centrado na tomada de poder pelos trabalhadores. Nesse sentido, Lefebvre é ideológico (para Castells), porque oculta o problema da divisão de classes como determinante para a dominação social. Então, tomada isoladamente, a crítica do espaço; da cidade e do cotidiano alienados não seria, sob o ponto de vista de Castells, suficiente para atacar o cerne do capitalismo e, assim, promover as mudanças necessárias na sociedade. Desse modo, visto sob esse prisma, o "direito à cidade" é uma luta dentro do capitalismo e, assim, insuficiente. Não só isso, mas a luta em prol do urbano lefebvriano sofre a crítica de ser uma abordagem espontaneísta. Ou seja, na visão de que a sociedade pode ser transformada pelas lutas dos excluídos da cidade, estaria contida a ideia de que não é preciso reunir os trabalhadores em torno de uma formação partidária, e de que, além disso, seria dispensável a tomada à força dos meios de produção. A luta pelo poder e a luta econômica seriam substituídas por uma luta pela cidade, ou pelo espaço, desse modo, uma luta não revolucionária por excelência.

Portanto, a caracterização de Castells das ideologias urbanas segue a definição de Marx e Engels de A ideologia alemã, consoante trazido anteriormente. 0 autor defende que, tanto a Escola de Chicago quanto o Lefebvre de $A$ revolução urbana, são ideólogos no sentido de que expõem uma teoria falsa, não calcada no problema da divisão de classes e que ocultam partes importantes dos processos sociais efetivos.

Na formulação do filósofo e sociólogo francês, a sociedade moderna atravessa um período de transição, uma mudança que conduzirá à urbanização completa da sociedade (o texto é publicado no início da década de 1970). 0 autor trabalha, portanto, com um objeto virtual, com o futuro, uma vez que essa sociedade é apenas hipotética. Na evolução do capitalismo, a chamada "sociedade industrial", que se desenvolveu nos países "avançados" e que se deu de forma incompleta nos países "atrasados", estaria, então, se movendo para uma sociedade (completamente) urbana (Lefebvre, 1999). A sociedade contemporânea, nesse sentido, atravessa um conjunto de transformações para passar do período em que predominam as questões de crescimento e de industrialização ao período no qual a problemática urbana prevalecerá decisivamente, em que a busca das soluções e das modalidades próprias à sociedade urbana passará ao primeiro plano (ibid. p. 19). Outrossim, nas suas últimas obras, como A produção do espaço e Espaço e política, Lefebvre defende, não a existência de um poder de determinação social por parte do espaço, mas uma interação com as relações sociais de produção - contradições da sociedade que 
emergem no espaço. Vale ressaltar que, como autor não economicista que é, Lefebvre refere-se à produção e reprodução das relações sociais e não à produção de coisas e do consumo (Limonad, 1999, pp. 72-73).

A nosso ver, portanto, Castells não chega ao cerne do pensamento de Lefebvre. Em primeiro lugar, porque não apreende que Lefebvre não dá à cidade um papel eterno. Assim, não é correto dizer que a cidade é tratada como uma unidade trans-histórica sem conteúdo social, apenas como forma que se perpetua. Até porque a "sociedade urbana só pode se formar sobre as ruínas da cidade clássica. Esta, no Ocidente, já explodiu. Explosão (explosão-implosão) que pode ser considerada como precursora da sociedade urbana" (Lefebvre, 1999, p. 155). Em segundo lugar, Castells parece não compreender que o "urbano" de Lefebvre é também um termo que designa a "cidade" comunista; aquilo que será construído como 0 espaço da vida pós-capitalista. Não é e não se pretende uma teoria sistemática da revolução, mas pode inspirar uma. A sociedade urbana de Lefebvre é

a liberdade de produzir diferenças, é a possibilidade de criar situações e gestos tanto ou mais que criar objetos. 0 urbano quer refundar a sociabilidade: 1) quer substituir o contrato pelo costume; 2) quer a reapropriação, pelo ser humano, de suas condições, no tempo, no espaço e nos objetos; 3) quer a autogestão da produção, das empresas e do território. (Paula, 2014, p. 243)

Assim, não é possível conceber outro espaço para a revolução que não o urbano (em formação). Esse espaço será palco, mas também será transformado pela revolução, na medida em que instituir outras práticas sociais, como o socialismo real falhou em construir. Em certo sentido, o próprio capitalismo inicia o processo de sua própria destruição e, desse modo, podem-se vislumbrar as virtualidades e as tendências do devir no presente real. 0 rigor da exposição marxista de Lefebvre reside em: postular a implosão do direito (de propriedade) como forma necessária do capitalismo e do Estado enquanto condutor dos negócios burgueses (independentemente do seu conteúdo de classe); e extinguir o valor (valor de troca) e a indústria como concebida até então. Nesse sentido, avençar uma teoria do espaço revolucionário faz sentido, já que a questão produtiva, após o capitalismo, será uma questão acessória. Mesmo na economia política do espaço, feita pelo geógrafo David Harvey, é possível ver que o espaço possui, principalmente na economia neoliberal financeirizada, um papel central na produção de mais-valia, na distribuição do mais-valor e nas crises do sistema, ou seja, é orgânico e funcionalmente relacionado à esfera da produção e da realização da mais-valia (Harvey, 2014, cap. 2). A partir da crise monetária da década de 1970, principalmente, alguns autores localizam uma mudança do capital alocado no circuito primário (indústria) para o secundário (terra, propriedade, ambiente construído), fato já antevisto pelo próprio Lefebvre (Gray, 2018, p. 326).

Acerca da classe operária, Lefebvre faz uma crítica que nos parece justa. Para ele, as reivindicações dessa classe não escapam do quantitativo, restringem-se, em grande medida, a melhores salários; nada tem a dizer sobre a instituição de outra forma de vida, outra relação de trabalho. Gottdiener (1997) chama a atenção para o fato de que, para Lefebvre, 
os conflitos interclasse são atravessados pelos antagonismos espaciais e não estão encerrados nos compartimentos estanques da teoria sociológica. Ao fim e ao cabo, a análise lefebvriana concentra-se no problema do valor, sua dialética (uso e troca) e a sua existência social, sendo a grande questão a ser resolvida pela sociedade urbana. A isso se liga, então, a noção de que o espaço, como todo produto do trabalho humano, ${ }^{8}$ não pode, numa sociedade emancipada, atrelar-se à forma valor. Nesse sentido, tratando das concepções tradicionais do marxismo, diz-nos Gottdiener que:

0 debate marxista [tradicional] com economistas "burgueses" gira em torno da organização social preferida para tomar essas decisões [de produção], onde o primeiro defende uma socialização dos meios de produção como a única solução para a violência no âmago de todos os outros sistemas de distribuição. (p. 133)

Assim como Postone (2014), defende-se a necessidade de rompimento com o marxismo ortodoxo e que centrar a crítica marxista apenas na economia política é uma incompreensão de sua obra de maturidade. É nesse sentido que Harvey (2014) nos relembra que Lefebvre era identificado com o grupo dos situacionistas, grupo que defendia a promoção de "situações revolucionárias", mais do que uma luta organizada via partidos, sindicatos, greves e manifestações.

No entanto, ainda que fiquemos nos esquemas mais clássicos, é Lefebvre quem afirma que na URSS houve a produção de superestruturas profundamente novas. "Essas superestruturas brotaram antecipadamente em relação às estruturas (relações sociais) e à base (forças produtivas). Teria sido preciso que a base e as estruturas avançassem [...]" para chegar ao nível alcançado no plano das ideias (Lefebvre, 1999, p. 167).

A conceituação do urbano com o conteúdo social dado pelos autores trazidos acima é fonte para que se trabalhe com um novo urbanismo não como produção de formas, mas de sociabilidades diferentes. As práticas sociais são espaciais: são condicionadas por ele e o modificam quando se alteram elas mesmas. É esse o sentido da revolução urbana que transforma práticas sociais as quais engendram novos espaços (heterotopias). Estes, por sua vez, retroagem sobre a sociedade produzindo e reproduzindo o discurso transformador e aglutinando novos corpos na luta pela emancipação do gênero humano, abrindo a via do possível.

\section{0 comum: direito, urbanismo e ideologia}

Antes de tratar diretamente das alternativas contemporaneamente em debate, é preciso tratar de outra forma superestrutural, além da cidade, que se interpõe entre as práticas sociais e o capital. Trata-se do problema do direito no capitalismo. Esse problema se liga diretamente ao problema do urbano em nossos autores, na medida em que o espaço apropriado privadamente é fonte das questões sociais candentes dessa discussão. A cidade (capitalista), em suma, nada mais é do que a agregação de pequenos espaços privados, ainda que alguns pertençam ao Estado - já que este é instância jurídica terceira na relação capital-trabalho e não se confunde com a sociedade civil. Porquanto o direito enquanto relação social perdura, 
perpetuam-se a forma mercadoria e, também, a reificação das relações humanas. Nesse sentido, como o espaço tem sido, cada vez mais, local de produção capitalista e de realização de lucro e exploração econômica, é justo que se reivindique o fim das apropriações de caráter antissocial como operadas hoje no neoliberalismo global.

Não obstante a questão da propriedade, deve-se ter em mente que o direito estrutura também todas as relações sociais no capitalismo, fazendo com que a relação social se resuma a sua dimensão contratual, de interesses. É esse tipo de alienação, do espaço e das relações fetichizadas, que Lefebvre busca abolir com sua teoria do urbano. Possivelmente o mais importante teórico do direito na tradição marxista, Pachukanis, diz-nos que o direito é uma produção do momento histórico capitalista. 0 desenvolvimento do mercado é o que cria a necessidade de se converter o homem em proprietário jurídico. "Só a sociedade burguesa capitalista cria todas as condições necessárias para que o momento jurídico alcance plena determinação nas relações sociais" (Pachukanis, 2017, p. 75). Por esse motivo, "Marx, portanto, concebia a transição para o comunismo desenvolvido não como uma transição para novas formas de direito, mas como a extinção da forma jurídica em geral, como uma extinção dessa herança da época burguesa que se destina a sobreviver à própria burguesia" (ibid., p. 79). Essa é, portanto, a finalidade última da sociedade comunista: o fim do direito e do estado, formas da sociabilidade capitalista e da forma valor (ver, também, Mascaro, 2013).

Para chegar ao estágio de abolição ou transformação do direito, entretanto, é preciso um momento de suspensão dos estranhamentos que compõem atualmente 0 cotidiano (trabalho, reprodução, mobilidade). Parece claro que o momento revolucionário precisa de uma preparação tanto objetiva quanto subjetiva, uma espécie de treinamento social, em que a população consegue vislumbrar (prática e ideologicamente) a viabilidade de outro modo de vida; que se invente outro sistema de sociabilidades que possa ser generalizado num segundo momento. Assim, esse postulado visa dialogar com aqueles que entendem, como Castells, que a mudança transformadora se dará, se e somente se, os trabalhadores tomarem para si o controle dos meios de produção. Parece óbvio que sem esse controle não há a passagem para outro modo de produção, e a exploração do homem pelo homem continuará, mas não é isso que contestamos. 0 postulado vem ao encontro de formulações que entendem que há outros meios estratégicos de transformação social, que, claro, culminarão com a organização da produção em outros moldes. Como ressalta Postone (2014), o inverso, a tomada anterior dos meios de produção para uma posterior invenção de práticas sociais novas, já foi tentado e fracassou, em grande medida. As estratégias atuais precisam se conformar às condições objetivas do neoliberalismo, à fase da grande indústria e às condições subjetivas entre os explorados. 0 fim último, a abolição do valor, tem sido perseguido e praticado de modo a antecipar a mudança concreta do sistema social capitalista e torná-la viável do ponto de vista político. Em suma, trata-se de adotar um marxismo que compreenda que ocorreram mudanças significativas na composição técnica e social na sociedade moderna, mas que essa sociedade é constituída por um plexo jurídico-social que transborda a 
questão produtiva em sentido econômico. Assim, ao menos duas proposições políticas nos dão, na contemporaneidade, saídas que complementam e dão suporte ao aporte lefebvriano. 0 papel das ideologias (agora no sentido luckacsiano) e o das práticas/instituição dos comuns. Comecemos pelo segundo.

\section{Conceituando o Comum}

Há na sociedade formas coletivas de entrar em acordo e criar regras de cooperação que não são redutíveis ao mercado e ao comando estatal. $E$ isso pode ser evidenciado empiricamente em muitos casos em que alguns grupos dispensaram sem nenhum prejuízo a coerção do Estado ou a propriedade privada [...]. (Dardot e Laval, 2017, p. 159)

No sentido contemporâneo, a noção de comum (no singular) toma a dimensão de uma produção social. Estão implicados, nesse termo, aqueles movimentos e coletivos que têm tomado ruas, praças e outros espaços urbanos (mesmo que privados) para a construção de algo novo, que possuem como cerne a questão da governamentalidade. Aqui não se refere aos bens ou espaços comuns (no plural) existentes na natureza ou mesmo produzidos pela sociedade, ressaltados apenas em seus aspectos físicos ou ontológicos. Para a compreensão dos movimentos sociais contemporâneos, devem ser rechaçadas aquelas concepções econômico-jurídicas que pretendem naturalizar o comum como uma característica intrínseca dos objetos. Assim, é mistificadora a proposição que consigna as lutas urbanas atuais como aquelas que visam apenas a resgatar a democracia no acesso de "bens comuns" ou "bens públicos".
Em última análise, como se tem visto no contexto de neoliberalização, nada há na natureza dos objetos, como as praças, o oceano, a costa, a água ou o ar, que possa os legar o estatuto de comuns, embora possa se conceder que estes têm sido historicamente protegidos pelas normas públicas e internacionais. Fato é que, sob 0 ataque mercantil, alguns grupos têm refletido sobre a condição política que o acesso a bens e espaços específicos possui e, mais do que isso, percebido a urgência em apropriar e gerir autonomamente aqueles espaços e recursos relevantes socialmente. A partir dessa motivação inicial, aparentemente reativa e essencialista, tem sido possível pensar alternativas diagonais a mercado e Estado, o que inaugura uma dimensão institucional nova e fora do direito de propriedade como constituído.

0 que defendem Dardot e Laval (2017) é que essas definições são sempre construídas socialmente, e, por isso, o governo de qualquer recurso tem o potencial de se transformar em uma gestão comum, como descrito na citação acima. Nesse sentido, os comuns, no plural, sempre existiram consensualmente na humanidade, principalmente antes do advento do capitalismo, quando a mercantilização se impôs a tudo e a todos. Assim, retomá-los num sentido novo tem sido o objetivo de diversos movimentos sociais que se espalharam por praças e espaços (públicos e privados) de cidades por todo o mundo. Esses termos (comum como substantivo ou comuns como adjetivo) ressurgiram no contexto da neoliberalização por que atravessaram (e atravessam) a quase totalidade dos países e refletem uma série de insatisfações sociais. Reivindica-se o direito de uso da cidade sob a forma de apropriação coletiva por aqueles que pretendem destiná-la a uma finalidade 
socialmente construída, em contraposição à racionalidade capitalista que tem promovido uma verdadeira "nova rodada de cercamentos" (Harvey, 2014). ${ }^{9}$ Do ponto de vista da dinâmica interna do capitalismo, alguns coletivos contemporâneos estão antepondo-se ao "devir-mundo do capital" (Dardot e Laval, 2017, p. 144), ${ }^{10}$ que privatiza a educação, a saúde, a previdência social, locais públicos, a água e 0 patrimônio cultural e genético, tanto humano como natural. Nesse sentido, a ressignificação daqueles objetos, espaços ou institucionalidades histórica e socialmente comuns tem sido feita pelas mãos das próprias pessoas pela produção social de um comum. Assim, por não ser centrada numa demanda ao Estado ou um movimento apenas reativo, a defesa dos comuns ganha uma dimensão política nova, quando as populações retomam espaços e instituem uma forma organizativa diferente das alternativas público-privadas, produzindo um comum.

Assim, algumas abordagens, quando tratam dos comuns, têm se mostrado problemáticas. Ora por tratar do comum como algo inerente e natural da produção humana tomada de modo trans-histórico, ora por vinculá-lo a um processo estruturado pelo capital e que inexoravelmente levará ao fim do capitalismo (ver Hardt e Negri, 2016), ora por tratá-los como "bens" à maneira da economia política convencional, ou por restringi-los a "bens públicos" mundiais a serem geridos nos moldes da eficiência econômica e associando-os a uma propriedade específica dos comuns ou mesmo pública (Dardot e Laval, 2017, p. 243). Para os autores franceses, a questão que deve ser atacada se liga ao problema do direito de propriedade ou do direito como relação social, como quer Pachukanis (2017). Parece claro, então, que
[...] ou o direito de propriedade é estabelecido como direito exclusivo e absoluto, e o comum fica apenas com um espaço residual, nos interstícios ou nas margens que a propriedade deixa de ocupar; ou 0 comum constitui o princípio de um novo direito que refundará toda a organização da sociedade, caso em que o direito de propriedade deve ser radicalmente contestado. (Dardot e Laval, 2017, p. 243) ${ }^{11}$

A questão do direito de ocupação, ou de outro tipo de "direito" fora do direito, remete aos artigos de Marx sobre a questão do furto da madeira (e à chamada "lei referente ao furto da madeira"), na antiga Renânia, e nos lança a uma concepção do direito como um corpo efetivado, tornado legal pelo costume ou, mais precisamente, pelo costume ou instinto jurídico dos pobres. É, em contraposição a Hegel, que Marx funda a noção de que aos costumes dos privilegiados não cabe a racionalidade da positivação legal, mas, sim, pela sua falta de universalidade, cabe à legislação liberal moderna a pecha de "não legal" ou irracional, já que o direito consuetudinário dos nobres "faz do interesse privado dos proprietários de florestas a medida do direito legal [...] e pretende perenizar privilégios anteriores à formação do direito legal" (Dardot e Laval, 2017, p. 359), de uma formação social anterior à conformação dos costumes caros a uma determinada sociedade.

Agora, vejamos que, para que se dê a instituição do comum, ou de um novo "direito" para além do direito, há que se fomentar as próprias práticas que se posicionam de maneira nova diante do problema da propriedade e do capital, uma vez que, contra o juspositivismo, é necessário que da concretude da vida emerjam as novas preocupações e as novas arquiteturas políticas e sociais. Trata-se de dizer, com isso, 
que não é de imposições externas ou novas leis que surgirá uma alternativa viável, mas sim do fazer e do processo é que serão delineadas novas estratégias, regras e costumes, daí a importância do novo urbanismo proposto de maneira seminal por Lefebvre. ${ }^{12}$ Assim, conforme Marcel Mauss, citado por Dardot e Laval (2017, p. 423), "será preciso parar de repetir que a tomada de poder político é a panaceia de todos os males". Porque não se trata apenas de tomar o poder, mas também de instituir novas formas de vida para que os homens se tornem socialistas, de viver tanto quanto possível a vida socialista imediatamente. Em certa medida, a afirmação quer dizer que não se instaura um costume, ele é criado pela prática humana.

Aprofundando-se a problemática do direito, da crítica e da inserção ao direito pela luta por uma "reforma" urbana, pode-se acrescentar algumas formulações. Vejamos que, porquanto as pessoas lutam por mais direitos, do ponto de vista pachukaniano, inserem-se cada vez mais como detentores da capacidade de terem respeitados os seus direitos como possuidores de mercadorias, ainda que só a mercadoria força de trabalho. Em nota, o russo chega a dizer que "se a burguesia admite o argumento sobre o tema das funções sociais da propriedade, é apenas porque este não a compromete seriamente. 0 real antípoda da propriedade não é a propriedade representada como uma função social, mas a economia socialista planificada, ou seja, a abolição da propriedade" (Pachukanis, 2017, p. 108). Trata-se de uma tentativa, aqui, da burguesia de justificar a existência social da propriedade e evitar o fim do capitalismo.

No mesmo sentido, uma luta negra ou feminista revolucionária, por exemplo, tem de se pautar a uma crítica inclusive do papel do direito, caso ela queira se inserir numa luta emancipatória de fato e não apenas se inscrever nas dominações a que os homens estão já inscritos. Essa indicação torna possível dizer que os processos revolucionários contemporâneos precisarão articular as interseccionalidades e daí talvez venha o caráter multiforme desses movimentos (ver Hardt e Negri, 2016).

\section{0 papel das ideologias}

É fato que as lutas contemporâneas se defrontam com características objetivas de um capitalismo diferente daquele dos séculos passados. A dinâmica de classe cada vez mais se amplia a âmbitos extrafabris. Se, no início do capitalismo, a quase totalidade do tempo dos trabalhadores era dedicada à produção, com os movimentos dos trabalhadores e os avanços tecnológicos, o tempo fora da produção é cada vez mais ampliado. No entanto, ao contrário do que podem pensar aquelas correntes que imaginam uma transição automática do capitalismo ao comunismo pelo simples avanço produtivo, esse tempo não tem sido disponibilizado ao engrandecimento da individualidade do trabalhador, mas sim capturado pelo sistema em novas formas de consumo. Seja pela indústria cultural, seja por formas secundárias de exploração (na extração de rendimentos dos trabalhadores pelos comerciantes, proprietários de terras e financistas), o trabalhador se encontra cada vez mais subsumido ao capital (Harvey, 2014, pp. 230-231). Nesse sentido, há, de fato, um deslocamento da questão fabril cara a Marx (século XIX) para as questões ligadas ao modo de vida total imposto pelo capital ao 
trabalhador, que retira todas as dimensões não mercantis do horizonte do ser humano. Conjuntamente a esses fatores, há, ainda, diversas questões que se ligam à dimensão ideológica ou discursiva.

Segundo Dardot e Laval, o comum constitui-se em uma nova razão política a substituir a racionalidade neoliberal que impera em nossos dias (2017, p. 608). Além disso, há um discurso de aversão aos movimentos que se propõem verdadeiramente revolucionários, e isso se deve a uma retórica, a uma ideologia (como discurso). Retomando o significado que Lukács dá ao termo, pode-se observar que os discursos que circulam hoje com maior visibilidade, de fato, têm minado esforços de movimentos sociais e exaltado os mercados e a propriedade como os verdadeiros objetivos da vida humana. Nesse sentido, a construção ou a melhor circulação de uma ideologia diversa (ou ideologias diversas) faz-se necessária para fomentar as ações de construção do comum.

Após os desenvolvimentos do marxismo do século XX, Lukács (2013) nos revela que "a ideologia é sobretudo a forma de elaboração ideal da realidade que serve para tornar a práxis social humana consciente e capaz de agir [...], é um meio da luta social, que caracteriza toda sociedade" (pp. 398-399). 0 autor dá à ideologia um papel real, confere-lhe um conteúdo social. Assim, poder-se-ia resumir sua formulação nos seguintes termos: a ideologia é o conjunto dos discursos que circulam socialmente e que produzem efeitos no real, não se constituindo por um conteúdo necessariamente verdadeiro nem necessariamente falso. No entanto, há de se atentar para o fato de que esses discursos não podem ser apenas individuais (têm de circular socialmente) e que "podem se converter em ideologia só depois que tiverem se transformado em veículo teórico ou prático para enfrentar e resolver conflitos sociais..." (ibid., p. 400). Para que não restem dúvidas, o autor húngaro nos dá ainda um exemplo iluminador:
A astronomia heliocêntrica ou a teoria do desenvolvimento no âmbito da vida orgânica são teorias científicas, podem ser verdadeiras ou falsas, mas nem elas próprias nem a sua afirmação ou negação constituem uma ideologia. Só quando, depois da atuação de Galileu ou Darwin, os posicionamentos relativos às suas con- cepções se converteram em meios para travar os combates em torno dos antago- nismos sociais, elas se tornaram operan- tes - nesse contexto - como ideologias. (lbid., p. 400)

Por fim, Bakhtin, também sob os ombros do marxismo do século $X X$ e da filosofia da linguagem, faz importante distinção. Para ele, "ao lado dos fenômenos naturais, do material tecnológico e dos artigos de consumo, existe um universo particular, o universo de signos" (2006, p. 30). Para o autor russo, o ideológico está no domínio do simbólico. Este é parte do real, mas não só isso como também o reflete e refrata; pode distorcer o real ou apreendê-lo corretamente. Nesse sentido, não se pode confundir o ideológico com um fenômeno da meramente da consciência. Trata-se de um fato social, uma criação humana; situa-se "entre indivíduos organizados, sendo o meio de sua comunicação" (ibid., p. 33). Em suma, o homem como ser de linguagem, trabalha sempre por metáforas e metonímias, como diria Nietzsche. Assim, na sua comunicação, faz uso de signos, significantes e significados, para se relacionar. A criação desses 
signos apreende parte do real, mas, como não corresponde inteiramente (e nem pode corresponder) a ele, torna-se ideológico, ou seja, torna-se linguagem, conceito; algo externo. É fato social, na medida em que os signos emergem apenas no terreno "interindividual" e, desse modo, "a palavra é o fenômeno ideológico por excelência", comporta uma função específica e tem sua razão de ser no desempenho dessa função (ibid., p. 34).

A partir dessas contribuições, pode-se dizer que, sem uma ideologia coerente, não haverá a formação de um amálgama político que dê consistência e rumo aos movimentos sociais que hoje tomam as ruas de todo o planeta. Os novos movimentos terão de ser conjugados a construções ideológicas coerentes para que se transformem em movimentos políticos de transformação social radical. 0 sentido dessa afirmação é que, ainda que se tenha em mente um marxismo ortodoxo que pense a programática revolucionária nos moldes do Manifesto Comunista, é possível dizer que às condições objetivas para se fazer a revolução é necessário, minimamente, organizar ideologicamente os trabalhadores para tal. Na conjuntura mundial contemporânea, essa batalha das ideias tem se dado em desfavor dos comunistas, fato que enseja esta reflexão. É Harvey que, analisando o movimento boliviano pela água na primeira década do século $X X I$, nos informa sobre o papel crucial de certa consciência de classe e de uma tradição indígena de práticas de tomada de decisões democráticas para a direção política verdadeiramente transformadora (Harvey, 2014, pp. 260-261). Nesse sentido, práticas organizativas novas, formadas de uma configuração singular de sindicatos, redes de solidariedade e organizações de vizinhança e setoriais foram inspiradas por um conjunto de ideias, as quais foram transformadas pela própria instituição dessas novas práticas sociais, de um novo comum, gerando outros discursos próprios.

A orientação ideológica aparece, assim, como algo necessário para que as contingências históricas ou as inovações políticas sejam direcionadas à superação dos estranhamentos capitalistas. A própria noção inventada por Lefebvre de "direito à cidade" deve ser compreendida em termos políticos; trata-se de uma direção para a prática social efetiva. No entanto, o significado que tem sido colado a essa noção permite interpretações reformistas que não estão, definitivamente, no horizonte lefebvriano (Gray, 2018). Assim, é possível dizer que se trata de um termo ambíguo e que necessita ser preenchido por significados politicamente transformadores para que atinja os objetivos que Lefebvre e Marx têm em mente, donde a importância tanto da teoria quanto da ideologia. A teoria, em Lukács, está diretamente articulada à dimensão ideológica. Como vimos, isso se dá quando a teoria orienta a práxis, seja ela uma representação correta dos determinantes do seu objeto de estudo ou não. Do ponto de vista do comum, as novas formas de organização da vida precisam se articular a um objetivo político, e uma ideologia própria tem de circular em contraposição àquelas que reproduzem a necessidade da propriedade privada e do consumo dirigido. No entanto, sendo fiel às concepções de Marx e Engels n'A ideologia alemã, só novas formas de fazer a vida podem ensejar novos construtos ideais, uma vez que estes não brotam do inexistente. 


\section{Considerações finais}

Seguindo o caminho delineado na introdução deste texto, concluo com algumas análises marxistas sobre alguns fatos concretos. $\mathrm{Na}$ análise que faz da Comuna de Paris de 1871, Lenin nos revela que Marx concluiu pela necessidade do desaparecimento do Estado, mas não se propôs a "descobrir as formas políticas desse futuro". Segundo a interpretação do russo:

A Comuna é a forma "enfim descoberta" pela revolução proletária, na qual se pode realizar a libertação econômica do trabaIho. A Comuna é a primeira tentativa da revolução proletária de quebrar a máquina de Estado burguesa e a forma política "enfim descoberta" pela qual se pode e se deve substituir o que foi quebrado. (Lenin, 2017, p. 79)

Nesse sentido, o que seria a Comuna, senão uma tentativa do proletariado, produtor da cidade no seu sentido físico e no de suas relações, de se reapropriar do seu produto alienado ${ }^{13}$ No entanto, defende-se, com Harvey, que é possível que este tenha sido um movimento ao mesmo tempo de classe e que visa a tomar as rédeas da construção do urbano; visa à tomada da cidade. Desse modo, se a problemática levantada por Marx ao longo de sua obra tem excepcional relevância nos nossos dias, é fato que a sua programática esboçada, por exemplo, no Manifesto comunista é datada historicamente e precisa-se de elaboração para trazê-la aos nossos dias.

É a partir dessa argumentação que se faz mister um esforço cada vez maior em compreender o mundo contemporâneo, e justificam-se as tentativas de teorização. Nesse diapasão, Gray (2018) argumenta pela necessidade de pensar em outros termos para a luta urbana contemporânea e utiliza do termo take over the city, mobilizado nos movimentos italianos trabalhistas das décadas de 1960 e 1970 em contraposição ao termo "direito à cidade". 0 chamado Operaísmo teve como base, ao contrário do que se poderia pensar, uma noção de autonomia contra a representação partidária, sindical e patronal (ibid., p. 324) e mobilizou pautas feministas, antitrabalho e grupos estudantis. Fundado na centralidade da práxis, uma lei (ou carta de direitos) instituída é vista por esses movimentos como a finalidade e não como o meio pelo qual se conseguem os direitos formais na democracia (ibid., p. 323). 0 autor chama a atenção para outro termo de Lefebvre potencialmente mais radical e em linha com as questões urbanas contemporâneas que é o da autogestão territorial, um conceito que dá ênfase ao caráter diagonal (em relação à oposição público-privado) contido nas práticas autogestionárias e incorporados nas práticas italianas descritas por Gray (2018). 0 princípio do comum cumpre, por seu turno, um papel semelhante, no sentido de dar a primazia para a instituição prática, para a ação. Em suma, trata-se de dizer que um esforço conceitual e teórico que descole o significado reformista das expressões utilizadas é importante para a transformação revolucionária.

Não obstante essas "utopias possíveis", é possível que o aprofundamento da lógica capitalista neoliberal acirre ainda mais as contradições e produza as condições objetivas para a sua transformação. Em conjunto com os comuns produzidos pela própria dinâmica do capital, a sociedade organizada tem produzido as condições subjetivas e as novas relações sociais de que falam Dardot e Laval (2017), ainda 
que de forma marginal e reativa em sua maioria. É, nesse sentido, que a ação política dos atores pode transformar o papel incipiente dos movimentos instituintes do comum numa nova sociedade urbana.

Conjugadas a essa reflexão, há possibilidades de aprendizagem metodológica com a sociologia urbana de Chicago no que diz respeito às necessidades que se impõem sobre 0 marxismo enquanto racionalidade, mais precisamente, para aumentar seu poder explicativo tendo em vista as sofisticações do capitalismo. 0 fato é que, não obstante a existência concreta das categorias extraídas por Marx (exploração, luta de classes, ideologia, fetichismo), a observação ativa e a etnografia dos grupos sociais, dos excluídos principalmente, (método que marca a Escola de Chicago), possibilitam ver, na prática, que se trata, essas estruturas, de lei tendenciais. Conforme aponta o próprio Castells, a questão, para Park, era utilizar a cidade como um laboratório social, um lugar de onde se extraem as questões importantes, e não como uma fonte de explicações (Castells, 1977, p. 77). Mais do que determinismos, pode-se enxergar as peculiaridades que, apesar de não escaparem aos vetores que atuam sobre a sociedade, produzem modos de vida próprios e que podem oferecer indícios para a construção de um modo de vida para além do capital. A avaliação dos novos modos de vida e das estratégias políticas do comum pode ser mais bem-feita por uma etnografia que faça o mapeamento dos erros, acertos e problemas práticos e teóricos. 0 próprio Harvey lança mão desses relatos para observar de que modo as insatisfações em El Alto (Bolívia) se conformaram e quais os determinantes da ação eminentemente transformadora que lá surgiu (Harvey, 2014).
No Brasil, Birman et al. (2015), por exemplo, realizam um empreendimento de grande monta nesse sentido, fazendo a composição do cenário urbano multifacetado do País. Em Birman (2015), em especial, uma tentativa de construção de um comum (em uma ocupação urbana carioca) é tratada nas suas potencialidades e também nas dificuldades e, no caso específico, são apontados os fatores da sua dissolução diante dos problemas encontrados.

Trata-se de dizer, em resumo, que, enquanto Marx captura com profundidade as contradições capitalistas, que continuam válidas enquanto houver capitalismo, a ele podem e devem ser acrescidas questões que só podem ser encaradas sob uma investigação ativista. Ou seja, o que se quer pontuar aqui é que métodos de imersão e o reconhecimento dos excluídos da sociedade podem e devem ser incluídos dentro do esquema geral marxiano, em dois pontos. Primeiramente, o sentido das articulações possíveis à esquerda entre esses grupos, LGBT's, negros, mulheres e outros, só será construído mediante o conhecer específico dessas realidades e sua inserção no quadro maior das explorações; diferentemente das acepções liberais, para fora das políticas compensatórias e inclusão destes como sujeitos de direitos. Em um segundo ponto, com o reconhecimento contemporâneo das insuficiências e das limitações humanas de conhecer, por meio das ciências, o saber-fazer das novas formas de vida comuns que podem advir nos interstícios do capital só pode aparecer com a participação ativa desses grupos na construção do conhecimento e da sociedade, e o papel do intelectual, nesse sentido, é o de um facilitador na proposição do debate e como participante, mais do que como um cientista/observador, como na concepção de Chicago. 


\section{[I] https://orcid.org/0000-0001-6865-3727}

Pontifícia Universidade Católica de Minas Gerais, Programa de Pós-Graduação em Ciências Sociais. Belo Horizonte, MG/Brasil.

victoraca.2010.1@gmail.com

\section{Notas}

(1) O que Marx busca fazer ao longo de sua obra é, consoante Postone (2014), uma crítica à economia política, fato que posiciona Marx para além da economia política crítica e de interpretações economicistas.

(2) Como em: "Não são apenas o tamanho imediato da área e o número de pessoas que, em função da correlação histórica universal entre o aumento do círculo e a liberdade pessoal interior e exterior, fizeram da metrópole o local da liberdade. É antes transcendendo essa expansão visível que qualquer cidade dada se torna sede do cosmopolitismo" (Simmel, 1967, p.19).

(3) Esta está presente, em alguma medida, no texto de Simmel, mas Park inclui noções como a de talento natural e de vocação, chegando a postular a existência de uma vocação para ser mendigo, furador de greve e agitador trabalhista (Park, 1967, p. 36).

(4) O próprio Marx faz menção aos manuscritos da Ideologia Alemã no prefácio da Contribuição à crítica da economia política e à inviabilidade da sua publicação à época da sua redação (1846). Com isso, é importante dizer que vários autores importantes do marxismo, como Lênin, Trótski, Gramsci e Rosa Luxemburgo, não tiveram acesso ao texto (lasi, 2018).

(5) As traduções de textos em língua estrangeira são próprias, salvo indicação em contrário.

(6) É importante notar que Castells se preocupou em observar que os regimes socialistas também apresentavam cidades semelhantes às dos países capitalistas, fato que o leva a indagar se, de fato, o socialismo conseguiu ser implantado com sucesso nesses locais; onde a forma urbana persistiu em moldes bem semelhantes ao capitalismo.

(7) Em A produção do espaço, Lefebvre relativiza a noção de ditadura do proletariado, substituindo-a pela noção gramsciana de hegemonia. Na caneta de Lefebvre, o processo de ascensão dos trabalhadores na era pós-capitalista se refere ao predomínio cultural, de valores e de saberes dessa classe (Lefebvre, 1991).

(8) À diferença que "ele recria continuamente relações sociais ou ajuda a reproduzi-las [...]" (Gottdiener, 1997, p. 133).

(9) Faz-se referência aqui aos cercamentos ocorridos na Inglaterra, no século XVI, e que deram ensejo ao capitalismo industrial pela via da transformação de espaços comunais em pastagens para a matéria-prima da indústria têxtil, a lã das ovelhas.

(10) Ver, nesse sentido, a última seção do capítulo 3 de Dardot e Laval (2017) em que os autores fazem uma crítica à noção de acumulação por despossessão de Harvey; inserindo a espoliação como característica intrínseca ao capitalismo. 
(11) Pachukanis não é citado por Dardot e Laval (2017) em nenhum momento da obra. É importante frisar que o russo prevê um comunismo por meio do fim do direito e não de sua refundação. No entanto, o tratamento conceitual que Dardot e Laval dão ao "direito do comum" nos permite aproximá-los. Estes chegam a fazer referência a texto do italiano Giorgio Agamben, em que ele conceitua o "uso" ou o "direito de uso" como algo extrínseco ao direito, o que nos parece ir ao encontro de Pachukanis (2017).

(12) Friso também que, não obstante as aproximações possíveis, Henri Lefebvre também não é sequer mencionado em Dardot e Laval (2017, p. 423).

(13) Castells, por sua vez, analisa o movimento de 1871 como eminentemente não capitalista (Harvey, 2014, p. 230), divergindo de Marx nesse caso.

\section{Referências}

BAKHTIN, M. (2006). Marxismo e filosofia da linguagem. São Paulo, Hucitec.

BIRMAN, P. (2015). "Ocupações: territórios em disputa, gêneros e a construção de espaços comuns". In: BIRMAN, P.; LEITE, M. P.; MACHADO, C. e CARNEIRO, S. de S. (orgs.). Dispositivos urbanos e trama dos viventes: ordens e resistências. Rio de Janeiro, Editora FGV, pp. 163-186.

BIRMAN, P.; LEITE, M. P.; MACHADO, C. e CARNEIRO, S. de S. (orgs.) (2015). Dispositivos urbanos e trama dos viventes: ordens e resistências. Rio de Janeiro, Editora FGV.

CASTELLS, M. (1977). The Urban Question: a marxist approach. Londres, Edward Arnold Publishers.

CHAUÍ, M. (2013). Manifestações ideológicas do autoritarismo brasileiro. Belo Horizonte, Autêntica e São Paulo, Editora Fundação Perseu Abramo.

DARDOT, P. e LAVAL, C. (2017). Comum: ensaio sobre a revolução no século XXI. São Paulo, Boitempo. FOUCAULT, M. (1999). A ordem do discurso. São Paulo, Loyola.

GOTTDIENER, M. (1997). A produção social do espaço. São Paulo, Edusp.

GRAY, N. (2018). Beyond the right to the city: territorial autogestion and the take over the city movement in 1970s Italy. Antipode. v. 50, n. 2, pp. 319-339.

HARDT, M. e NEGRI, A. (2016). Bem-Estar Comum. Rio de Janeiro, Record.

HARVEY, D. (2014). Cidades rebeldes: do direito à cidade à revolução urbana. São Paulo, Martins Fontes. HORKHEIMER, M. (2015). Eclipse da razão. São Paulo, Editora Unesp.

IASI, M. (2018). Léxico Marx \#2: O conceito de Ideologia. TV Boitempo, YouTube, 28 de fevereiro de 2018. Disponível em: <https://www.youtube.com/watch?v=P6uQ1-KNSD>. Acesso em: 28 fev.

LEFEBVRE, H. (1991). The production of space. Oxford, Blackwell Publishers. (1996). Writings on cities. Oxford, Blackwell Publishers. (1999). A revolução urbana. Belo Horizonte, Editora UFMG. 
LENIN, V. I. (2017). O Estado e a revolução: a doutrina do marxismo sobre o Estado e as tarefas do proletariado na revolução. São Paulo, Boitempo.

LIMONAD, E. (1999). Reflexões sobre o espaço, o urbano e a urbanização. GEOgraphia, v. 1, n. 1, pp. 71-91.

LÖWY, M. (2014). A jaula de aço: Max Weber e o marxismo weberiano. São Paulo, Boitempo.

LUKÁCS, G. (2013). Para uma ontologia do ser social, v. 2. São Paulo, Boitempo.

MARX, K. e ENGELS, F. (2007). A ideologia alemã. São Paulo, Boitempo. (2010). Manifesto comunista. São Paulo, Boitempo.

MARX, K. (1947). Misère de la philosophie. Paris, Éditions Sociales. (2008). Contribuição à crítica da economia política. São Paulo, Expressão Popular.

MASCARO, A. L. (2013). Estado e forma política. São Paulo, Boitempo.

PACHUKANIS, E. B. (2017). Teoria Geral do Direito e Marxismo. São Paulo, Boitempo.

PARK, R. E. (1967). “A cidade: sugestões para a investigação do comportamento humano no meio urbano”. In: VELHO, G. (org.). O fenômeno urbano. Rio de Janeiro, Zahar, pp. 25-66.

PAULA, J. A. de (2014). Crítica e emancipação humana: ensaios marxistas. Belo Horizonte, Autêntica.

POLANYI, K. (2012). A Grande Transformação: as origens de nossa época. Rio de Janeiro, Elsevier.

POSTONE, M. (2014). Tempo, trabalho e dominação social: uma reinterpretação da teoria crítica de Marx. São Paulo, Boitempo.

SIMMEL, G. (1967). "A metrópole e a vida mental”. In: VELHO, G. (org.). O fenômeno urbano. Rio de Janeiro, Zahar, pp.10-24.

VELHO, G. (org.) (1967). O fenômeno urbano. Rio de Janeiro, Zahar.

WIRTH, L. (1967). “O urbanismo como modo de vida”. In: VELHO, G. (org.). O fenômeno urbano. Rio de Janeiro, Zahar, pp. 89-112.

Texto recebido em 19/set/2018

Texto aprovado em 26/fev/2019 
